\title{
REDIMAT
}

Journal of Research in Mathematics Education

Instructions for authors, subscriptions and further details:

http://redimat.hipatiapress.com

\section{The Mathematics of Mathematics. Thinking with the Late, Spinozist Vygotsky}

Vladia lonescu ${ }^{1}$

1) Universitat de Barcelona, Spain.

Date of publication: February $24^{\text {th }}, 2018$

Edition period: February 2018-June 2018

To cite this article: lonescu, V. (2018). The mathematics of mathematics. Thinking with the late, Spinozist Vygotsky [Review]. REDIMAT, 7(2), 216218. doi: 10.4471/redimat.2018.3590

To link this article: http://dx.doi.org/10.4471/redimat.2018.3590

\section{PLEASE SCROLL DOWN FOR ARTICLE}

The terms and conditions of use are related to the Open Journal System and to Creative Commons Attribution License (CC-BY). 


\section{Review}

Roth, W-M. (2017). The Mathematics of Mathematics. Thinking with the Late, Spinozist Vygotsky. Dordrecht, The Netherlands: Springer.

U

In the preface, Wolff-Michael Roth presents us Lev Vygotsky as the psychologist that had influenced theories of learning and development but who had also recognized that his theories must be reviewed. Willing to do so, Vygotsky remembered philosopher Spinoza and agreed with the idea of the existence of a unique substance, the thinking body, that has different ways to turn out. To get even further, Vygotsky applied Karl Marx principles learned from "The German Ideology", in which theories went around the idea of "the primacy of societal relations" that makes the difference between humans and other species. Combining Spinoza and Marx through Vygotsky's unfinished and unrevised theories led the author to write "The Mathematics of Mathematics" and see where Vygotsky's last work could imply for mathematics education.

Wolff-Michael Roth divides the book in ten chapters. The first one, "Vygotsky's Marxist-Spinozist Re/Orientations", the author describes how Baruch Spinoza and Karl Marx's works influenced the final work of Vygotsky. In his "Ethics", Spinoza wrote that mind as thought and body as extension were the same thing, meaning that they are attributes of the substance. To understand this idea, different illustrations appear in the chapter, demonstrating that you can see the image as one (the rabbit) or the other (the duck), but not both at the same time. In "The German Ideology", Marx delved into how mathematics becomes individual when children are aware how they relate with others.

The second one, "The Thinking Body", readers are able to differentiate between the classical approaches of the mathematical thinking regarding the individual mind and the individual body and to conclude that Vygotsky overcomes them through the Spinozist-Marxian lens. The third one, "The Mathematics of Mathematics" applies to the social role of mathematics by 
understanding what students do as a social construction, which is the same as understanding a person as a social unit, a part of a specific societal group.

In the fourth chapter, the author illustrates what Vygotsky calls "sociogenesis" or what happens when mathematical reasoning is used for the first time by someone in the relation to another person. To show these findings, the author uses different figures illustrating children in their mathematics' interactions.

Chapter five links the material and the ideal physical world by bridging the gap among different speakers when the author introduces the idea of mediation and mediators. "Experiencing Mathematics" or Pereživanie define person and environment as "parts of the same system", both united in one substance. When linked to a maths classroom, any performance carried out needs to be considered one single unit - "person-acting-in-environment" -.

Chapter six (Affect and emotion) and seven (teaching/Learning) present activities in class: first, a case study of affect in Mathematics to illustrate how children react when they are hand over a task and which relations are built among them and second, how kids interact under the teacher's instructions. In chapter nine, Mathematics in the Drama of Life, the author intends to understand mathematics and how we apply them to solve situation that we must manage. To explain it, Wolff-Michael Roth appeals to the research his team and himself carried out in a fish hatchery and what he found out from the mentor-mentee relation of two of the workers.

The last chapter "Overcoming Dualism", we finally overcome "the traditional dichotomy of body and mind" from the beginning.

The author provides mathematics educators a first sight of the Marxist reading and re-articulation of the Spinozist idea of the substance. Educators can avoid the dualist theory and use this book as a tool to improve their teaching methods and the way students learn. The importance of overcoming the traditional dualism that Wolff-Michael Roth presents in his work, based on reviewing theories of the great philosophers, implies assuming new methods of understanding how we know, learn and develop during our lifetime and how to do it through mathematics.

Reviewing traditional theories that worked years ago helps teachers and educators to understand and to support their students with updated methods. Mind and body as one, understanding the classroom as part of the learning process and accepting emotion as part of it, among others, provide new ways to see how mathematics are part of our existence. Thus, educators manage 
218 Vladia Ionescu - The Mathematics of Mathematics

the how to teach mathematics and students the why of the usefulness of mathematics.

Vladia Ionescu, Universitat de Barcelona vladia.ionescu@gmail.com 